\title{
FOOD AND FEEDING HABITS OF MANGROVE SHELLFISH, TELESCOPIUM TELESCOPIUM (LINNAEUS, 1758) IN BANGLADESH
}

\author{
M. Beniaz Zaman* and M. Sarwar Jahan ${ }^{1}$ \\ Department of Zoology, Khulna Public College, Khulna-9000, Bangladesh
}

\begin{abstract}
Experiments on food and feeding behaviour of Telescopium telescopium was conducted in the Sundarbans and surrounding area during January to December 2008. The stomach contents of 960 individuals were examined, in which $74.79 \%$ and $25.21 \%$ were found with and without food respectively. Of the $74.79 \%$ stomach with food $16.98 \%, 18.23 \%, 21.14 \%$ and $18.44 \%$ were full fed, $3 / 4$ fed, $1 / 2$ fed and $1 / 4$ fed respectively. The intensity of feeding in tidal cycle and monthly sampling periods showed a clear trend. The snail fed mainly at low tide and preferred grazing at day time in winter and night in summer in spring tide. They consumed fine particulate mud along with organic detritus from upper intertidal surface sediment using its long extensible snout. In the time of neap tide especially in winter when the muddy habitat of Telescopium telescopium became dry, the animal survived a long time without food.
\end{abstract}

Key words: Telescopium telescopium, feeding, Sundarbans.

\section{INTRODUCTION}

Telescopium telescopium have wide distribution in the swamps of the Sundarbans of Bangladesh. It is one of the most commercially important shellfishes in Bangladesh. The species is highly delicious food for the local tribal people, Munda (Zaman et al. 2011). At present, there is no effort to culture it; in addition the exploitation from the wild and excessive harvest pressure considerably affected the abundance and community structure of the species. In spite of that, it is relatively cheap source of animal protein for the poor tribal people and the shell is used in lime production and calcium source for animal feeds. Presently, the market demand for this mollusc appears to be very high. Knowledge of activities and behaviour such as food and feeding periodicity of the economically important animal is essential for conservation and cultivation of the species.

Like other animals, snails require adequate nutrition for growth and survivability. For successful conservation of Telescopium telescopium a through knowledge on food and feeding habits is of immense importance. By studying food and feeding habit, the pattern of intra and inter species competition of snails can easily be known. Notably some works on food and feeding habits of molluscs have been carried out by Maeda (1986), Dye (1993), Jahan and Raut

*Corresponding author. E-mail: beniaz_zaman@yahoo.com ${ }^{1}$ Institute of Environmental Science, University of Rajshahi, Rajshahi-6205, Bangladesh. 
(1994) and Saha et al. (2004). Food and feeding habits of different species of mangrove gastropods were also studied by Branch and Branch (1980), Nishihira (1983), Slim et al. (1997), Fratini et al. (2000, 2001, 2004 and 2008), Barnes (2003), Chapman et al. (2005), Pape et al. (2008) and Penha-Lopes et al. (2009). Telescopium telescopium are common on soft mangrove mud, feeding on organic material and algae on the surface. Many authors (Alexander et al., 1979; Das et al., 1988; Houbrick, 1991; Anand et al. 1996; Rakshit et al. 1997 and Meziane and Tsuchiya, 2002) clearly reported that Telescopium telescopium is detritus feeder. Yet no work is available on feeding habits of this snail in Bangladesh. Accordingly, an effort was made to study the food and feeding habits of the snail in its unique habitat, the Sundarbans reserve forest area.

\section{MATERIAL AND METHODS}

Determination of feeding periodicity of Telescopium telescopium was based on 24 hours period of fishing in each month, once at every 7 days interval according to lunar cycle; one in full or new moon and next in mid moon, during the period from January to December 2008. Each time, fishing was done at every 6 hours interval according to tidal cycle; one in high tide and another in low tide. Every time a group of 10 adult fresh snails was collected through careful handpicking method (Chunkuri Patrol Camp at Kadamtala station in Satkhira range under the division of west Sundarbans) for their stomach analysis. Just after collection, snails were preserved in $10 \%$ formalin. After being brought to the laboratory, the living adult specimens were removed from their shells by cracking them with hammer, tongs and stone piece carefully without damaging the soft tissues. A cut was made across the stomach. Only the volumes of stomach contents were examined with a large magnifying glass. The examined stomachs were categorized as follows:

\begin{tabular}{ll}
\hline Stomach status & Description \\
\hline $\begin{array}{l}\text { Empty stomach }(\mathrm{E}) \\
\text { Quarter fed stomach }(1 / 4 \mathrm{~F})\end{array}$ & $\begin{array}{l}\text { Stomach with almost no food } \\
\text { Food occupying about one fourth of } \\
\text { the total volume of stomach }\end{array}$ \\
Half fed stomach $(1 / 2 \mathrm{~F})$ & $\begin{array}{l}\text { Food occupying about half of the total } \\
\text { volume of stomach }\end{array}$ \\
Three quarter fed stomach $(3 / 4 \mathrm{~F})$ & $\begin{array}{l}\text { Food occupying about three fourth of } \\
\text { the total volume of stomach } \\
\text { Full stomach }(\mathrm{F})\end{array}$ \\
\hline
\end{tabular}


Volume of stomach contents for each individual was recorded. Finally, mean values of feeding periodicity of each period in each month were calculated for seasonal representation.

\section{RESULTS AND DISCUSSION}

Food: It was found that Telescopium telescopium grazed on mangrove detritus (deteriorated and semi decade leaves of mangrove plants). The gut content of the snail indicated that it consumed large quantities of fine particulate mud along with organic detritus from the intertidal surface sediment. It was also evident from their very small radular structure that they feed on fine particulate leaf litter. They were common on soft mangrove mud, feeding on organic material on the surface. The snail fed at low tide using its long, extensible snout to engulf fine mud and detritus from the surface of mudflats.

Seasonal and Overall Feeding Intensity: Overall and month wise percentages of stomach status of snails examined during the year 2008 are presented in Table 1. Out of 960 stomachs examined, $74.79 \%$ and $25.21 \%$ were found with and without food respectively. Of the $74.79 \%$ stomach with food $16.98 \%$, $18.23 \%, 21.14 \%$ and $18.44 \%$ were full fed, $3 / 4$ fed, $1 / 2$ fed and $1 / 4$ fed respectively.

Table 1. Overall and monthwise percentage of stomach status of Telescopium telescopium ( $N=960)$

\begin{tabular}{lcccccc}
\hline $\begin{array}{l}\text { Month } \\
(2008)\end{array}$ & $\begin{array}{c}\text { Full fed } \\
(\%)\end{array}$ & $\begin{array}{c}3 / 4 \text { fed } \\
(\%)\end{array}$ & $\begin{array}{c}1 / 2 \text { fed } \\
(\%)\end{array}$ & $\begin{array}{c}1 / 4 \text { fed } \\
(\%)\end{array}$ & $\begin{array}{c}\text { Empty } \\
(\%)\end{array}$ & $\begin{array}{c}\text { Total no. } \\
\text { of snails }\end{array}$ \\
\hline January & 00.00 & 00.00 & 06.25 & 20.00 & 73.75 & 80 \\
February & 00.00 & 02.50 & 08.75 & 26.25 & 62.50 & 80 \\
March & 12.50 & 20.00 & 37.50 & 20.00 & 10.00 & 80 \\
April & 13.75 & 22.50 & 33.75 & 23.75 & 06.25 & 80 \\
May & 23.75 & 30.00 & 27.50 & 15.00 & 03.75 & 80 \\
June & 35.00 & 32.50 & 22.50 & 10.00 & 00.00 & 80 \\
July & 47.50 & 32.50 & 20.00 & 00.00 & 00.00 & 80 \\
August & 38.75 & 28.75 & 21.25 & 07.50 & 03.75 & 80 \\
September & 18.75 & 30.00 & 26.25 & 17.50 & 07.50 & 80 \\
October & 13.75 & 15.00 & 30.00 & 22.50 & 18.75 & 80 \\
November & 00.00 & 05.00 & 12.50 & 33.75 & 48.75 & 80 \\
December & 00.00 & 00.00 & 07.50 & 25.00 & 67.50 & 80 \\
Overall (\%) & 16.98 & 18.23 & 21.14 & 18.44 & 25.21 & \\
\hline
\end{tabular}

Daily Feeding Periodicity: Summarized results of daily feeding periodicity are given in Table 2 . Maximum $70 \%$ full fed stomachs were obtained at spring low tide in day in the month of July; 60\% full fed stomachs were obtained at neap low tide in day and spring low tide in night in the month of July; $50 \%$ full fed stomachs were obtained at neap high tide in day and neap low tide in night in 
the month of July; $40 \%$ full fed stomachs were obtained at spring high tide in day in the month of August, spring high tide in night in the month of June and August and neap high tide in night in the month of May.

Table 2. Summarized result of feeding periodicity of Telescopium telescopium

\begin{tabular}{|c|c|c|c|}
\hline $\begin{array}{l}\text { Sequences of months } \\
\text { according to percent of } \\
\text { full fed stomach }\end{array}$ & $\begin{array}{l}\text { Sequences of } \\
\text { feeding periods for } \\
\text { full fed stomach }\end{array}$ & $\begin{array}{l}\text { Sequences of months } \\
\text { according to percent of } \\
\text { empty stomach }\end{array}$ & $\begin{array}{l}\text { Sequences of } \\
\text { feeding periods for } \\
\text { empty stomach }\end{array}$ \\
\hline July $>$ August $>$ & SLTD>NLTD> & January> December $>$ & NHTN $>$ NHTD $>$ \\
\hline June $>$ May $>$ & SLTN $>$ NHTD $>$ & February > & NLTN $>$ SHTN $>$ \\
\hline September $>$ April $>$ & NLTN $>$ SHTD $>$ & November $>$ & NLTD $>$ SHTD $>$ \\
\hline October $>$ March $>$ & SHTN $>$ NHTN & October $>$ March $>$ & SLTN>SLTD \\
\hline January $>$ February $>$ & & September $>$ & \\
\hline November > & & April> May> & \\
\hline December & & August $>$ June $>$ July & \\
\hline \multicolumn{2}{|c|}{ SLTD $=$ Spring Low Tide in Day } & \multicolumn{2}{|c|}{ SLTN = Spring Low Tide in Night } \\
\hline \multicolumn{2}{|c|}{ SHTD $=$ Spring High Tide in Day } & \multicolumn{2}{|c|}{ SHTN $=$ Spring High Tide in Night } \\
\hline \multicolumn{2}{|c|}{ NLTD $=$ Neap Low Tide in Day } & \multicolumn{2}{|c|}{ NLTN $=$ Neap Low Tide in Night } \\
\hline \multicolumn{2}{|c|}{ NHTD $=$ Neap High Tide in Day } & \multicolumn{2}{|c|}{ NHTN $=$ Neap High Tide in Night } \\
\hline
\end{tabular}

On the contrary, maximum $90 \%$ empty stomachs were obtained at neap high tide in night in the months of January; $80 \%$ empty stomachs were obtained at neap high tide in day and spring high tide in night in the months of January and neap low tide in night in the month of December; $70 \%$ empty stomachs were obtained at neap low tide in day in the month of January, spring high tide in day and spring low tide in night in the months of January and December and $60 \%$ empty stomachs were obtained at spring low tide in day in the months of January and December.

Detritus-feeding invertebrates dominated the mangrove fauna (Chapman et al. 2005). Potamidids were primarily grazers or detritus feeders, mobile, largely marine in shallow water, especially in mangrove swamps (Morton, 1968). It is generally considered that mangrove litter falls were important source of energy and material input into a mangal benthic community and adjacent shallow water marine communities, since degraded mangrove litters were important base of detritus-based food web. Potamidid snails were dominant members among the mangrove gastropods and depend principally on detritus (Nishihira, 1983). The detritus energy pathway was a conspicuous feature of the mangrove ecosystem. Detritus consisted of materials in a various stages of microbial decomposition and represented an important energy source for consumer species: crustaceans, molluscs and fishes. During decomposition in the mangrove litter, the organic substance was broken down into finer detritus particles, which formed part of the food of Telescopium telescopium (Anand et al. 1996). 
Telescopium telescopium mainly inhabits where the substratum was muddy and rich in detritus. The preference for muddy deposits might be correlated with the fact that the species was detritus or deposit feeder, taking in mud and digesting the detritus and other organic matter in it. Das et al. (1988), Houbrick (1991), Rakshit et al. (1997), Anand et al. (1996) and Meziane and Tsuchiya (2002) reported that Telescopium telescopium is detritus feeder as is also evident from their very small radular structure. The extensible snout of Telescopium telescopium is almost proboscis-like in function. Indeed, the small radula, jaws and buccal mass also contrast with the large size of the animal and reflect the fine particulate food eaten by it. The large, complex stomach is typical of members of the Potamididae and is highly adapted to deal with the fine particulate matter ingested. In the present study no coarse material was found in the gut content of the snails without fine particulate mud with organic matter.

Alexander et al. (1979) found a definite trend towards reducing style enzyme levels at high tide and increasing the enzyme levels at low tide. This trend follows the feeding routine of the snail: they only feed at low tide, withdrawing into their shells when covered with water. Rhythmic feeding and digestion related to the tidal cycle have been demonstrated in various gastropods and bivalves and this is only possible in those animals inhabiting the upper littoral zones which have extended periods of exposure during low tides. This is the case for Telescopium telescopium, which may only be under water for 3-4 hours during one tidal cycle.

Lasiak and Dye (1986) mentioned that Telescopium telescopium can feed only at low tide. Nevertheless, Budiman (1988) opined that Telescopium telescopium can maintain its feeding activity from its burrow by using its long, extensible snout, even when covered by high tide. This study revealed that the snails can graze even in high tide in warm and calm environment but they mainly graze on exposed mudflats in low tide.

The enzymatic activity of Telescopium telescopium was maximum at salinities between 20 and $25 \mathrm{ppt}$ and pH between 8 and 8.6 (Anand et al. 1996 and Prosia, 1999). Probably for this dietary reason Telescopium telescopium preferred high salinity and $\mathrm{pH}$ consisting habitat like the west Sundarbans.

Feeding activity of Telescopium telescopium increased in spring and comparatively more in night time. Similar findings are reported by Slim et al. (1997) for the related mangrove snail Terebralia palustris in a mangrove forest in Kenya. It was observed that Telescopium telescopium can live 3 to 4 months without food like Terebralia palustris as reported by Rao (1938) which lives in similar type of habitat, and is of the same size. 
Acknowledgement: The authors are highly grateful to the Forest Authority of the Sundarbans for providing requisite co-operation to conduct the study and to Islamic Bank Foundation for financial assistance.

\section{LITERATURE CITED}

ALEXANDER, C.G., CUTTER, R.L. and YELLOWLESS, D. 1979. Studies on the composition and enzyme content of the crystalline style of Telescopium telescopium (L.) (Gastropoda). Comp. Biochem. Physiol. 64B: 83-89.

ANAND, T.P., PATTERSON, J. and AYYAKKANNU, K. 1996. Lytic activity of gut microflora of the prosobranch Telescopium telescopium L., Pichavaram mangrove, Southeastern India. Phuket Mar. Biol. Cent. Spe. Pub. 16: 311-318.

BARNES, R.S.K. 2003. Interactions between benthic molluscs in a Sulawesi mangal, Indonesia: the cerithiid mud-creeper Cerithium coralium and potamidid mud-whelks, Terebralia spp. J. Mar. Biol. Ass. U.K. 83: 483-487.

BRANCH, G.M. and BRANCH, M. 1980. Competition in Bembiciam auratum (Gastropoda) and its effect on microalgal standing stocks in mangrove muds. Oecologia 46, 106-114.

BUDIMAN, A. 1988. Some aspects of the ecology of mangrove whelk Telescopium telescopium (Linné, 1758) (Mollusca, Gastropoda: Potamididae). Treubia, 29(4): 237-245.

CHAPMAN, M.G., MICHIE, K. and LASIAK, T. 2005. Responses of gastropods to changes in amounts of leaf litter and algae in mangrove forests. J. Mar. Biol. Ass. U.K. 85: 1481-1488.

DAS, S., MISRA, K.K. and GHOSE, K.C. 1988. Scanning electron microscope studies on radular teeth of three gastropod molluscs (Prosobranchia: Mesogastropoda). Proc. Zool. Soc. Calcutta 37:71-79.

DYE, A.H. 1993. Recolonization of intertidal macroalgae in relation to gap size and molluscan herbivory on a rocky shore on the east coast of southern Africa. Mar. Ecol. Prog. Ser. 95: 263271.

FRATINI, S., CANNICCI, S. and VANINI, M. 2000. Competition and interaction between Neosarmatium smithi (Crustacea: Grapsidae) and Terebralia palustris (Mollusca: Gastropoda) in a Kenyan mangrove. Marine Biology 137: 309-316.

FRATINI, S., CANNICCI, S. and VANINI, M. 2001. Feeding cluster and olfaction in the mangrove snail, Terebralia palustris (Linnaeus) (Potamididae : Gastropoda). J. Exp. Mar. Biol. Ecol. 261:173-183.

FRATINI, S., VIGIANI, V., VANNINI, M. and CANNICCI, S. 2004. Terebralia palustris (Gastropoda; Potamididae) in a Kenyan mangal: size structure, distribution and impact on the consumption of leaf litter. Marine Biology 144: 1173-1182.

FRATINI, S., VANINI, M. and CANNICCI, S. 2008. Feeding preferences and food searching strategies mediated by air and water-borne cues in the mud whelk Terebralia palustris (Potamididae: Gastropoda). J. Exp. Mar. Biol. Ecol. 362: 26-31.

JAHAN, M.S. and RAUT, S.K. 1994. Distribution and food preference of the giant African land snail, Achatina fulica Bowdich in Bangladesh. J Asiat. Soc. Bangladesh Sci. 20(2): 111-115.

HOUBRICK, R.S. 1991. Systematic review and functional morphology of the mangrove snails Terebralia and Telescopium (Potamididae; Prosobranchia). Malacologia 33: 289-338.

LASIAK, T. and DYE, A.H. 1986. Behavioural Adaptation of the Mangrove Whelk, Telescopium telescopium (L.), to Life in a Semi-terrestrial Environment. J. Moll. Stud. 52: 174-179.

MAEDA, T. 1986. Interrelationships of types of osphradium, habitat and food habit of the Cerithioidea and its near superfamilies (Mesogastropoda). Venus, 45: 31-41. 
MEZIANE, T. and TSUCHIYA, M. 2002. Organic matter in a subtropical mangrove-estuary subjected to waste water discharge: origin and utilization by two macrozoobenthic species. J. Sea Res. 47: $1-11$.

MORTON, J.E. 1968. Mollusks. Hutchinson University Library, London. 244 pp.

NISHIHIRA, M. 1983, Grazing of the mangrove litters by Terebralia palustris (Gastropoda: Potamididae) in the Okinawan mangal: preliminary report. Galaxea 2: 45-58.

PAPE, E., MUTHUMBI, A., KAMANU, C.P. and VANREUSE, A. 2008. Size-dependent distribution and feeding habits of Terebralia palustris in mangrove habitats of Gazi Bay, Kenya. Estuarine, Coastal and Shelf Science 76: 797-808.

PENHA-LOPES, G., BOUILlON, S., MANGION, P., MACIA, A. and PAULA, J. 2009. Population, structure, density and food sources of Terebralia palustris (Potamididae: Gastropoda) in a low intertidal Avicennia marina mangrove stand (Incha Island, Mozambique). Estuar. Coast. Shelf. Sci. 84: 318-325.

PROSIA, E.J.P. 1999. Survival and behavior of the telescope snail Telescopium telescopium (Linne) at different salinities. Thesis BS Biology, College of Arts and Sciences, Univesity of Philippines in the Visays, Miagao, Iliolo, Philippines.

RAKSHIT, S., BHATTACHARYYA, D.K. and MISRA, K. 1997. Distribution of major lipids and fatty acids of the estuarine gastropod mollusc Telescopium telescopium. Folia biologica 45(1-2): 83-87.

RAO, H.S. 1938. Observation on the growth habits of the gastropod mollusc Pyrazus palustris Linn. in the Andaman waters. Rec. Indian Mus. 38: 499-502.

SAHA, B.K., HOSSAIN, M.A. and JAHAN, M.S. 2004. Food and feeding habits of the freshwater apple snail, Pila globosa (Swainson, 1822) (Gastropoda : Prosobranchia). Bangladesh J. Zool. 32(1): 57-62.

SLIM, F.J., HEMMINGA, M.A., OCHIENG, C., JANNINK, N.T., MORINIERE, E.C. and VELDE, G.V. 1997. Leaf litter removal by the snails Terebralia palustris (Linnaeus) and sesarmid crabs in an East African mangrove forest (Gazi Bay, Kenya). J. Exp. Mar. Biol. Ecol. 215: 35-48.

ZAMAN, M.B., JAHAN, M.S. and RAHMAN, M.R. 2011. Mollusc resources harvested from the Sundarbans of Bangladesh. Proceedings of the International Conference on Environmental Technology and Construction Engineering for Sustainable Development, SUST, Sylhet, Bangladesh. March 10-12. 